Vol. 2, No. 2, pp. 132-146, (June 2021)

DOI: $10.21608 / A U J E S .2021 .65086 .1012$

Aswan University Journal of Environmental Studies (AUJES)

Online ISSN: 2735-4237, Print ISSN: 2735-4229

Journal homepage: https://aujes.journals.ekb.eg/

Original research

\title{
Impact of Nutrients and Water Quality in some Khors of Lake Nasser,
} Egypt

\author{
Mostafa Korium \\ National Institute of Oceanography and Fisheries, Aswan, Egypt
}

Received: 25/2/2021

Accepted: 7/5/2021

(C) Unit of Environmental Studies and Development, Aswan University

\begin{abstract}
:
Nutrient and water quality in some khors of Lake Nasser has been carried out with the aim to determine in variation seasonally as well as change of water quality based on some physicchemical properties of four main khors in Lake Nasser, Water samples were collected from many sites for each khor as shown on the map. Seasonally changes in properties of many parameters such as temperature, $\mathrm{pH}$ and oxygen dissolved in water to study their effect on the concentration of nutrients $\left(\mathrm{NH} 3, \mathrm{NO}_{2}^{-}, \mathrm{NO}_{3}^{-}, \mathrm{PO}_{4}^{3-}\right.$ and $\left.\mathrm{SiO}_{2}^{2-}\right)$ in 2013 , where an increase in nitrate concentration and phosphate are indicative of eutrophication. Temperature plays important role in plankton's distribution and lake stratification. Where minimum values were recorded during winter, but maximum values were observed during summer, $\mathrm{pH}$ values were on the slightly alkaline side, fluctuated between 7.21-9.37. High mean value for D.O. $12.1 \mathrm{mgl}^{-1}$ was detected in khor Kalabsha during winter, then in khor Toushka $7.7 \mathrm{mgl}^{-1}$ during autumn. The concentration of $\mathrm{NH}_{3}$ ranged between 1.86 to $810 \mu \mathrm{g} \mathrm{NH}_{3} \mathrm{l}^{-1}$, for $\mathrm{NO}_{2}$ showed variations from zero to $76.35 \mathrm{ugl}^{-}$

1. The concentrations of $\mathrm{NO}_{3}^{-}, \mathrm{PO}_{4}^{3-}$ and $\mathrm{SiO}_{2}^{2-}$ were measured and fluctuated between 213838.8, ND-312 $\mathrm{ugl}^{-1}$ and 1.7-8.9 $\mathrm{mgl}^{-1}$ respectively. Consequently, the average values of concentrations between different parameters from four khors sites under study were investigated to calculate correlation coefficient ( $r$ ) to know effect and relation between them. From obtained results, the study pointed out good quality of the water in these four khors under study in different seasons and best use for drinking water, pisclculture irrigation, domestic and other uses.
\end{abstract}

Keywords: Main lake Nasser khors, Physico-chemical parameters, nutrients, water quality.

\section{1- INTRODUCTION}

The High Dam of Aswan Lake is known as lake Nasser (330 km) which man-made as the main source of fresh water in Egypt since the concentration of Aswan High Dam 1964 and to store a huge amount of water during high floods. The reservoir extends from the dam itself in the north to the cataract Dal, Sudan in the south (Lake Nubian $170 \mathrm{~km}$ ).

Corresponding author*: E-mail address: mostafakorium@yahoo.com 
Lake Nasser lies between latitudes $22^{\circ} 00^{\backslash}-23^{\circ} 58^{\backslash} \mathrm{N}$ and longitudes $31^{\circ} 19^{\backslash}-33^{\circ} 13^{\backslash}$ E. Lake Nasser is irregular in shape and has a large number, 48 is located on the eastern side and 37 on the other side (Entz, 1973). These khors include about 79\% of the total area; kalabsha and Tushka are the biggest khors, while khor Korosko is steep and narrow (Latif, 1984). The khors play important role for growing fishes, specially, tilapias that favourite khors for its habitats (ElShabrawy and Dumont, 2003). The highest flood level recorded since the construction of Aswan High Dam was 181.3m MSL during November 1998. Again the water level in October 2000 was recorded level more than capacity of High Dam reservoir and flood water entire in the Toushka canal. The study of phsico-chemical and biological characteristics refer to water quality which it is predetermined by the intended uses, as well as each of these uses affects, more or less, its quality (El-Halag et al., 2013).

A large amounts of nutrient are carried into lake Nasser during annual floods from Blue andWhite Nile catchments, where the lake becomes rich in nutrients. Lake Nasser may be become gradual eutrophication result of continuous organic matter sedimentation which accumulates annually with flood water rich in nutrients (Abdel El-Monem, 1995).

Eutrophication accelerates by the increasing trend of nutrient enrichment of many fresh water bodies and growth of many aquatic organisms, which exerts agreat surge to the ecosystem in fresh water bodies. Source of fresh water contains, micro and macro nutrient concentrations within the permissible limit. This study carried out with aim to assess the effect of seasonal and regional changes in concentrations of nutrient in some khors under study would be important to obtain clear results for sustainable use of aquatic habitats. Chemical element particulary nutrients are very important to the development of plant and animal life. Therefore healthy lakes and stream, must be contain suitable amount of nutrients which are needed for the growth of algae that form base in food chain provide the entire aquatic ecosystem. On the other side, the water quality in khors of Nasser Lake influence by the fertilizer release from farmlands around of studied khors. Several studied were carried in some khors in Lake Nasser given by several authors (Elewa, 1988, ; Iskaros, 1993; Rabeh, 2001; Korium, 2001; El-Shabrawy and Dumont, 2003; Goher and Ali, 2009; El-Shabrawy, 2014; Hesham and Soad, 2014; Toufeek and Korium, 2015 and Howayda et al., 2016).

Nitrogen and phosphorus compounds are most common nutrients in lakes and streams. Under good conditions, including suitable nutrient concentrations, algae and aquatic plants to grow and reproduce well, then continous growth and die, microorganisms break it down, consuming oxygen dissolved from the water hence aquatic organisms will die due to decrease of oxygen in water. Consequentaly fish kills as a result in lack of oxygen.

Increase growth of algae cause an increase in the water's $\mathrm{pH}$, this can be toxic to fish and other organisms, as well as increase in ammonia concentrations, become more toxic to aquatic organisms and fish, also excess nutrient affect human health and livestock. As well as increase concentrations of nitrate in drinking water, about $10 \mathrm{mg} / \mathrm{l}$ or greater cause human infants or kill livestock. Human activity has increased amounts of nitrate in lakes and streams.

All studies about levels of nitrogen and phosphorus in Lake Nasser are generally measured in micro and milligrams per liter and in generally quiet and within the permissible limit natural sources of nitrogen include organic debris from riparian vegetation, where soil and rocks are natural sources of phosphorus in the form of phosphates. 


\section{2- MATERIALS AND METHODS}

\subsection{Study Area}

Four main khors were studied lying in the stream of Lake Nasser. These were khor Kalabsha and khor Wadi-Abyad with 7 and 6 sites respectively in the northern part of the lake khor Tushka and Korosko with 6 and 8 sites respectively, in the southern part. Water samples were seasonally collected during 4 seasons, winter (February to Autumn) 2013. The program for sampling water was supported by the National Institute of Oceanography and Fisheries (NIOF). The longitude and latitude of the different stations in the studied khors are measured by using GPS in (Fig. 1, Table 1).
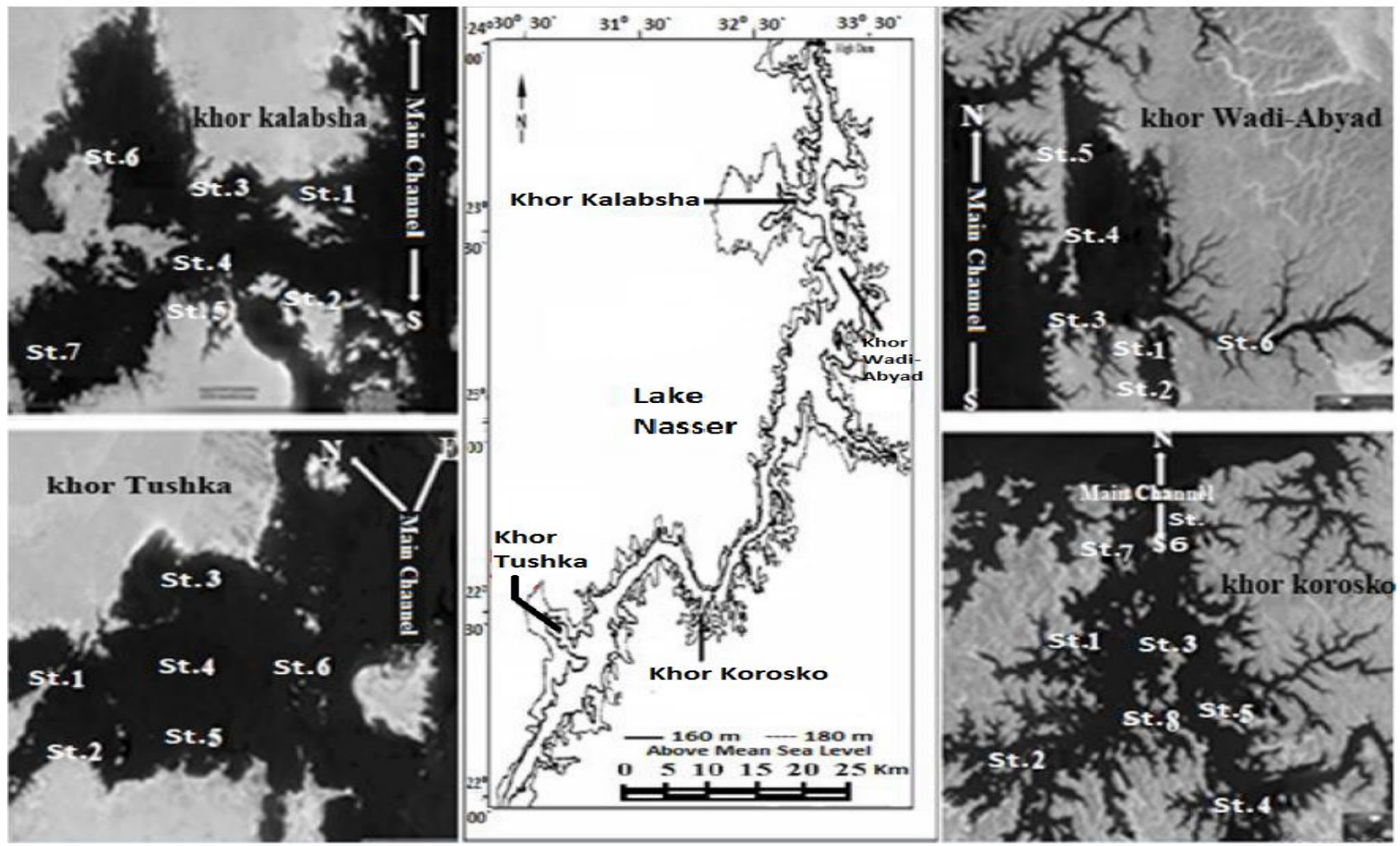

Fig. 1: A map showing location of selected sampling stations in some main khors in Lake Nasser, Egypt.

\subsection{Method Analysis for Water Sampling}

Samples of water were collected using Polyvinyl Van Dorn Polyethylene bottle (2L) from the chosen sites (Fig. 1) during 4 successive seasons in 2013 and kept in clean plastic bottles. Water temp. $\left({ }^{\circ} \mathrm{C}\right)$ and hydrogen ion concentration $(\mathrm{pH})$ were registered immediately by using $\mathrm{pH}$ meter model (CRISON INSTRUMENTS MM40t).

\subsection{Laboratory Work}

Dissolved oxygen (DO) was determined by the modified Winkler's method using azide modification of iodometric method. A few drops of mercuric sulphate were added as preservation of water samples for the determination of nutrients, the samples were filtrated through No. 42 filter paper, nitrite $\left(\mathrm{NO}_{2}^{-}\right)$was measured in a strongly acid medium ( $\left.\mathrm{pH} 2-2.5\right)$ by coupling diazotized Sulfanilamide which reacts with N 1-naphthyl ethylenediamine dihydrochloride (N.E.D) to form strongly coloured azocompound measuring spectrophoto-metrically at wave 
length $543 \mathrm{~nm}$. Hydrazine reduction method is used for $\left(\mathrm{NO}_{3}^{-}\right)$estimation at which nitrate is reduced to nitrite by hydrazine sulfate in alkaline solution then the nitrite originally present plus reduced nitrate is determined by diazotization with sulfanilamide and coupling with $\mathrm{N}$ 1-naphthyl ethylenediamine dihydrochloride to form a reddish purple azo dye which is measured spectrophotometrically at $543 \mathrm{~nm}$. Phenate method is used for ammonia estimation at which an intensely blue compound (indophenol) is formed by the reaction of ammonia, hypochlorite and phenol catalyzed by sodium nitroprusside then this intensely blue compound is measured

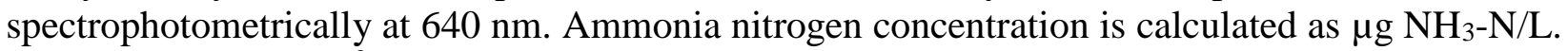
Orthophosphate $\left(\mathrm{PO}_{4}{ }^{3-}\right.$ was determined by stannous chloride method using spectrophotometer model $6800 \mathrm{uv} / \mathrm{vis}$ at wavelength $690 \mathrm{~nm}$, the soluble reactive silicate was determined by molybdate method according to (APHA, 1998).

Table (1): Location and features of sampling sites by global positioning system (GPS).

\begin{tabular}{|c|c|c|c|c|c|c|}
\hline Khor & $\begin{array}{c}\text { Distance } \\
\text { from H.D } \\
(\mathrm{km})\end{array}$ & $\begin{array}{c}\text { Length } \\
\mathrm{km}\end{array}$ & $\begin{array}{c}\text { Surface } \\
\text { area } \\
\left(\mathrm{km}^{2}\right)\end{array}$ & $\begin{array}{l}\text { Average } \\
\text { depth } \\
\text { (m) }\end{array}$ & Latitude & Longitude \\
\hline Kalabsha & 50 & 47.20 & 620 & 19.57 & $\begin{array}{l}1-23^{\circ} 35^{\backslash} 8.47^{\prime \prime} \\
2-23^{\circ} 31^{\backslash} 53.85^{\prime \prime} \\
3-23^{\circ} 35^{\backslash} 36.42^{\prime \prime} \\
4-23^{\circ} 33^{\backslash} 21.71^{\prime \prime} \\
5-23^{\circ} 31^{\backslash} 16.92^{\prime \prime} \\
6-23^{\circ} 36^{\prime} 46.59^{\prime \prime} \\
7-23^{\circ} 30^{\prime} 18.85^{\prime \prime}\end{array}$ & 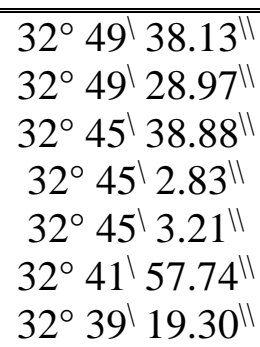 \\
\hline Wadi-Abyed & 74 & 18.30 & 48.2 & 21.85 & $\begin{array}{l}1-23^{\circ} 21^{\backslash} 39.62^{\prime \prime} \\
2-23^{\circ} 20^{\backslash} 55.56^{\prime \prime} \\
3-23^{\circ} 21^{\prime} 59.25^{\prime \prime} \\
4-23^{\circ} 23^{\backslash} 15.10^{\prime \prime} \\
5-23^{\circ} 24^{\backslash} 31.76^{\prime \prime} \\
6-23^{\circ} 21^{\backslash} 43.55^{\prime \prime}\end{array}$ & \begin{tabular}{|cccc}
$32^{\circ}$ & $59^{\prime}$ & $44.99^{\prime \prime}$ \\
$33^{\circ}$ & $0^{\prime}$ & $1.03^{\prime \prime}$ \\
$32^{\circ}$ & $58^{\prime}$ & $53.74^{\prime \prime}$ \\
$32^{\circ}$ & $58^{`}$ & $57.78^{\prime \prime}$ \\
$32^{\circ}$ & $58^{`}$ & $25.59^{\prime \prime}$ \\
$33^{\circ}$ & $14^{\backslash}$ & $6.14^{\prime \prime}$
\end{tabular} \\
\hline Korosko & 167 & 22.56 & 83.6 & 36.0 & 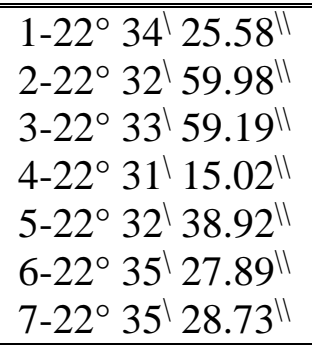 & 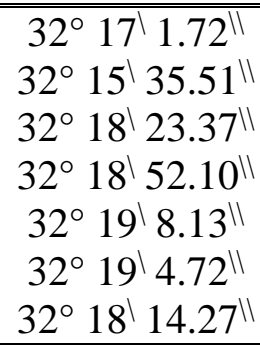 \\
\hline Toushka & 240 & 15.02 & 66.9 & 16.83 & $\begin{array}{c}1-22^{\circ} 37^{\backslash} 50.12^{\| \prime} \\
2-22^{\circ} 36^{\backslash} 0.97^{\|} \\
3-22^{\circ} 35^{`} 49.49^{\| \prime} \\
4-22^{\circ} 34^{\backslash} 25.82^{\|} \\
5-22^{\circ} 33^{\backslash} 14.10^{\prime \prime} \\
6-22^{\circ} 32^{`} 1.51^{\prime \prime}\end{array}$ & 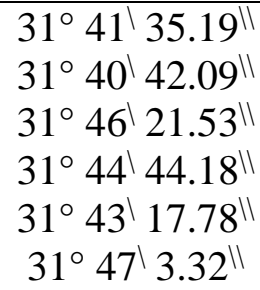 \\
\hline
\end{tabular}

\subsection{Statistical Analysis}

Results were analyzed according to Pearson's correlation coefficient matrix ( $r$ ) and probability between two variable pairs to assess their strength. 


\subsection{Water Temperature}

\section{RESULTS AND DISCUSSION}

Temperature is very important for water quality and aquatic life. Many of the physical, biological and chemical properties are affected by temperature, which directly affects the aquatic ecosystem such as plants and organisms, its influence on limnological phenomena as stratification, gas solubility, $\mathrm{pH}$ and planktonic are known (Singh et al., 2008). Water temperature $\left({ }^{\circ} \mathrm{C}\right)$ in the study khors show a maximum in summer and fluctuated between $24.3^{\circ} \mathrm{C}$ at khor Wadi-Abyad to $31.7^{\circ} \mathrm{C}$ at $\mathrm{K}$. Korosko, while during winter, the values of temperature ranges of $17.0^{\circ} \mathrm{C}$ at K. Kalabsha to $22.3^{\circ} \mathrm{C}$ at K. Korosko. From Tables (2-5), the complete circulation developed in the winter and the difference between surface and bottom water temperature is slight change. This due to the complete mixing between different water layers in the whole Lake Nasser. In contrast, there is a wide variation between surface and bottom water layer during summer (Table 3, Fig. 2) indicating progressive development of thermocline consequently formation strong thermal stratification in water column especially in the northern part of the lake. High in temperature leads to faster chemical and biochemical reactions. In addition, the kinetics of the biochemical oxygen demand and the growth or death of microorganisms are also controlled to some extent by water temperature (Toma, 2011).

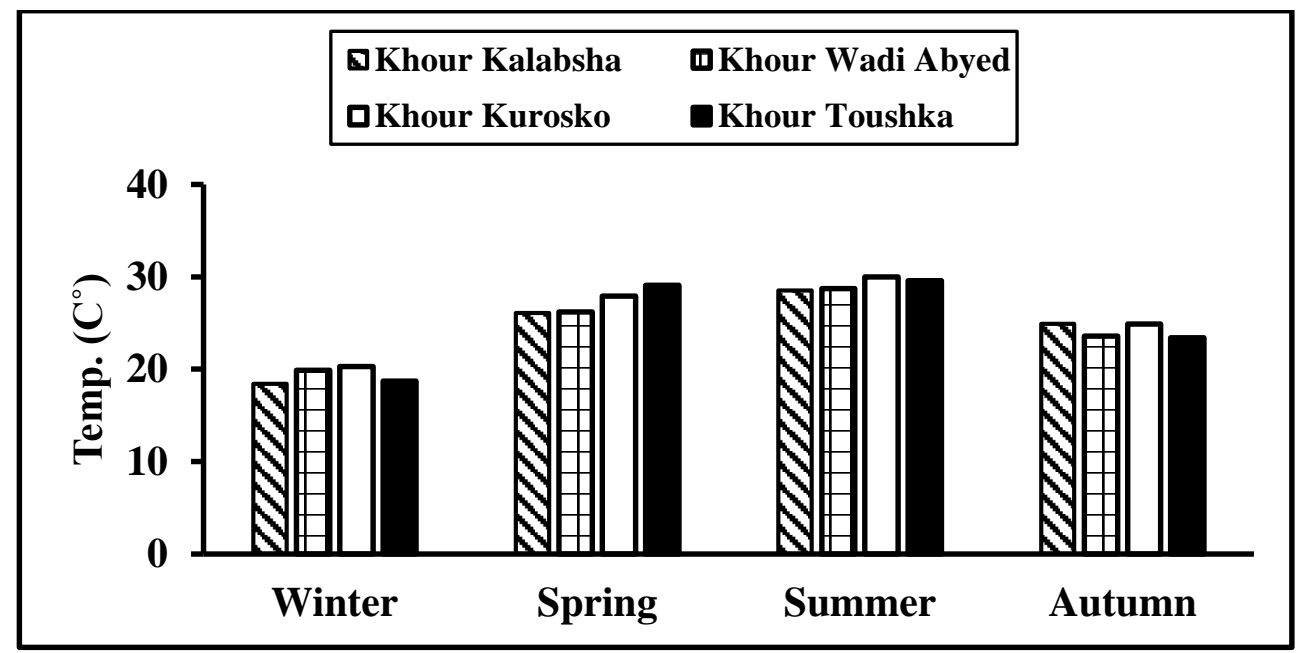

Fig. 2: Seasonal mean variations of temperature $\left({ }^{\circ} \mathrm{C}\right)$ in different sites of each khor in Lake Nasser water during 2013.

Water temperature has important influence on dissolved oxygen contents and this shown by the negative correlation between temperature and dissolved oxygen contents $(r=-0.753)$, (Table 6). Increased temperature leads to decrease growth rates of algae (Singh et al., 2008).

\section{2. pH (Hydrogen Ion Concentration)}

In the aquatic ecosystem $\mathrm{pH}$ value around 7 is more active for most aquatic organisms (Goldman and Horne, 1983). In other wise most aquatic organisms can tolerate to reasonable $\mathrm{pH}$ range $(6.0-9.0)$. the range of $\mathrm{pH}$ values in different khors water show a mark fluctuation for the different sites where, the variation fluctuated between $8-9.337,7.72-9,7.21-8.86$ and $7.31-$ 8.77 during winter, spring, summer and autumn respectively. From the data obtained, (Tables $2-$ 5, Fig. 3), all the $\mathrm{pH}$ values lie on the alkaline side with relatively low seasonal variations. This may be due to high production of the free $\mathrm{CO}_{2}$ during photosynthesis of micro-macro-organisms, which make the water a little alkalaline (Trivedy, 1989; Shiddamallayya and Pratima, 2008). As soon as increase values of $\mathrm{pH}$ might be occure the high photosynthetic due to the abundance of 
the algal population, with the reduction available free $\mathrm{CO}_{2}$, and increase of carbonate, also high $\mathrm{pH}$ indicate low organic matter in khors of Lake Nasser. In generally, the $\mathrm{pH}$ of water controlled by the carbon dioxide bicarbonate system (Hutchinson, 1975). Finally from the obtained data, our study is accepted.

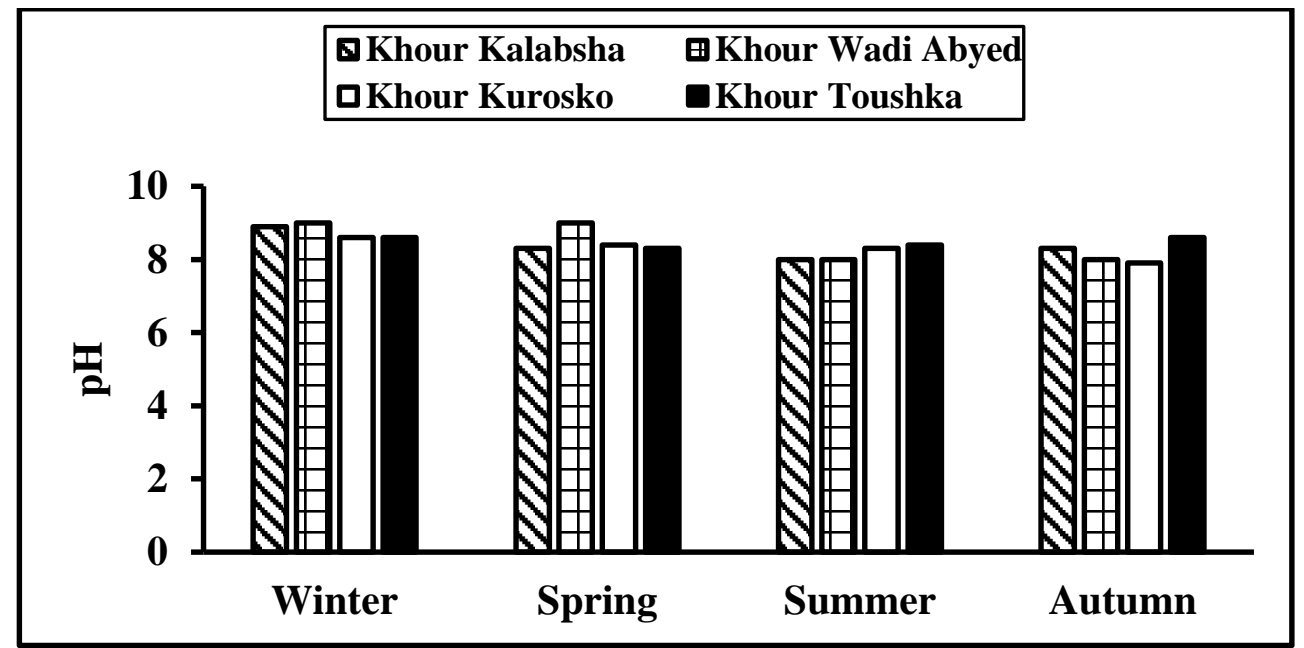

Fig. 3: Seasonal mean variations of $\mathrm{pH}$ in different sites of each khor in Lake Nasser water during 2013.

WHO (1993) for drinking water reported that the ideal $\mathrm{pH}$ ranges between 7 to 8.0 while the permissible range from 6.5 to 9.2 for different aquatic life. The negative correlation between temperature and $\mathrm{pH}(\mathrm{r}=-0.547)$, this point to increase $\mathrm{pH}$ with decreasing temperature i.e increase $\mathrm{pH}$ during winter, Tables (2-6). In reverse conditions $\mathrm{pH}$ decrease during higher water temperature due to the decomposition of organic matter and the liberation of hydrogen sulphide and carbon dioxide (Tables 3-4, Fig. 3). Solubility of $\mathrm{CO}_{2}$ and essential nutrients affected by the $\mathrm{pH}$ concentration which have a significant impact on algal metabolism, maximum algal growth occurs about neutal pH (Chen and Durbin, 1994).

\subsection{Dissolved oxygen (DO)}

Seasonal and regional variations in the concentrations of dissolved oxygen, where the results exhibit ranging from 4.2-8.2, 2.0-8.5, 0.9-5.7 and 1.4-8.4 $\mathrm{mgl}^{-1}$ during winter, spring, summer and autumn respectively, (Table 2-5). Maximum seasonal mean concentrations during winter, particularly at $\mathrm{K}$. Kalabsha $\left(12.1 \mathrm{mgl}^{-1}\right)$, and a minimum average concentration during summer (3.5 $\mathrm{mgl}^{-1}$ ) at $\mathrm{K}$. Korosko, (Fig. 4) this can be attributed to several changes as the rise in temperature, where a negative correlation $(\mathrm{r}=-0.753)$, in addition increased biological activity, respiration of organisms and decomposition of organic matter (Goldman and Horne, 1983). Solubility of many inorganic nutrients affect the distribution of DO, a weak correlation between nutrients and DO (Table 6), this may be due to seasonal shifts from aerobic to an aerobic changes in some regions (Benson et al., 1980). On the overall oxygen is a very important factor in controlling or affecting the fish movements. The fish tend to choose high oxygenated water (Korium, 2001). Generally, the distribution of dissolved oxygen varies vertically in water column and the photosynthetic production. Finally dissolved oxygen is removed during summer through respiration by bacteria and other animals and oxygen demand consumed by the decomposition of organic materials. As well as the solubility of oxygen is lowered in high temperature. 


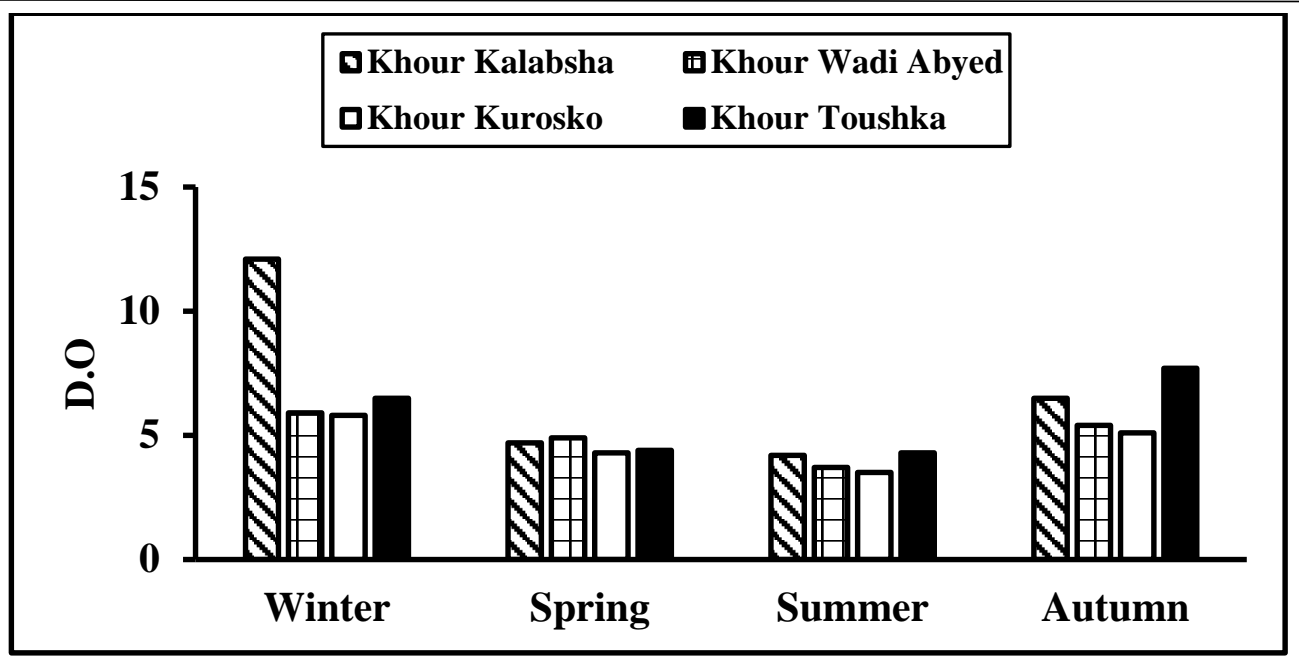

Fig. 4: Seasonal mean variations of D.O mgl-1 in different sites of each khor in Lake Nasser water during 2013.

\section{Nutrient}

\subsection{Ammonia (NH3-N)}

Ammonia can be used as an indicator for the degree of pollution, trace amounts of ammonia $\left(\mathrm{NH}_{3}\right)$ are present in fresh water due to reduction of atmospheric nitrogen by aquatic organisms.

$$
\mathrm{N}_{2}(\mathrm{~g})+3 \mathrm{H}_{2} \leftrightarrow 2 \mathrm{NH}_{3}(\mathrm{aq})
$$

Ammonia concentrations were slight variations seasonal and regionally ranged between 0 318.5, 18-501, 18-685 and 10-810 $\mu \mathrm{g} \mathrm{NH}_{3} \mathrm{l}^{-1}$ during winter, spring, summer and autumn respectively, the highest absolute value $\left(810 \mu \mathrm{g} \mathrm{NH}_{3} \mathrm{l}^{-1}\right)$ was recorded during autumn and the lowest $\left(1.86 \mu \mathrm{g} \mathrm{NH}_{3} \mathrm{l}^{-1}\right)$ at $\mathrm{K}$. Toushka during winter. As a whole, average means maximum values were recorded during spring and summer, (Tables 3-4, Fig. 5), while at low average mean values were recorded during winter and autumn (Tables 2, 5), these results are documented by there is correlation between concentration $\mathrm{NH}_{3}$ and temperature of water $(\mathrm{r}=0.603)$ and reverse concentration with DO $(r=-0.278)$, this can be shown in (Tables 2-6, Fig. 5) where at decrease in temperature and a neutral $\mathrm{pH}$, ammonia is become at equilibrium with non-toxic ammonium ion.

$$
\mathrm{NH}_{3}+\mathrm{H}_{2} \mathrm{O} \leftrightarrow \mathrm{NH}_{4}^{+}+\mathrm{OH}^{-}
$$

The relative increase in the ammonia occurs naturally to the denitrification process by the reduction of $\mathrm{NO}_{2}^{-}$and $\mathrm{NO}_{3}^{-}$. In addition $\mathrm{NH}_{3}$ a rising in water bodies from the microbiological decomposition of nitrogen compounds in organic matter, fish and other aquatic organisms that excrete ammonia. EPA during 2013 reported that the criterian maximum value for fresh water is $17 \mathrm{mgl}^{-1}$ as total-ammonia (including both $\mathrm{NH}_{3}$ and $\mathrm{NH}_{4}$ ).

\subsection{Nitrite}

Nitrite concentrations fluctuated between $0-76.35,0-58,4-34$ and $1.6-19.6 \mu \mathrm{gNO}_{2} \mathrm{l}^{-1}$ during four seasons respectively. The lowest mean nitrite values were observed during summer and autumn, where a weak negative correlation between temperature, dissolved oxygen and $\mathrm{NO}_{2}$ ( $\mathrm{r}=-0.116,-0.086$ respectively) (Tables 2-6) i.e there is a reversible relation between concentration of $\mathrm{NO}_{2}$ and both of temperature and D.O. The well oxygenated or saturated water 
responsible for the oxidation of ammonia, yielding nitrite as intermediate state during winter (Wetzel, 1983). This also clear the decrease in the values of ammonia content during the same period. On the other side during hot period and low of oxygen content (Tables 2-5, Fig. 6), there is a relative decrease in the nitrite concentrations, this may be due to the reduction into ammonia (this is supported by the relative increase in the ammonia contents) during this period. In addition, $\mathrm{NO}_{2}$ oxidized by nitrifying bacteria to nitrate or uptake by the phytoplankton. Latif and Elewa (1980), Rabeh et al. (2001) and Goma (2001) studied the concentrations of $\mathrm{NO}_{2}-\mathrm{N}$ as 5 $180,0.0-7.1$ and 3.0-68.4 $\mathrm{Mgl}^{-1}$ respectively. During 2006 the range was 2.4-44.1 $\mu \mathrm{gl}^{-1}$ (Goher and Ali, 2009).

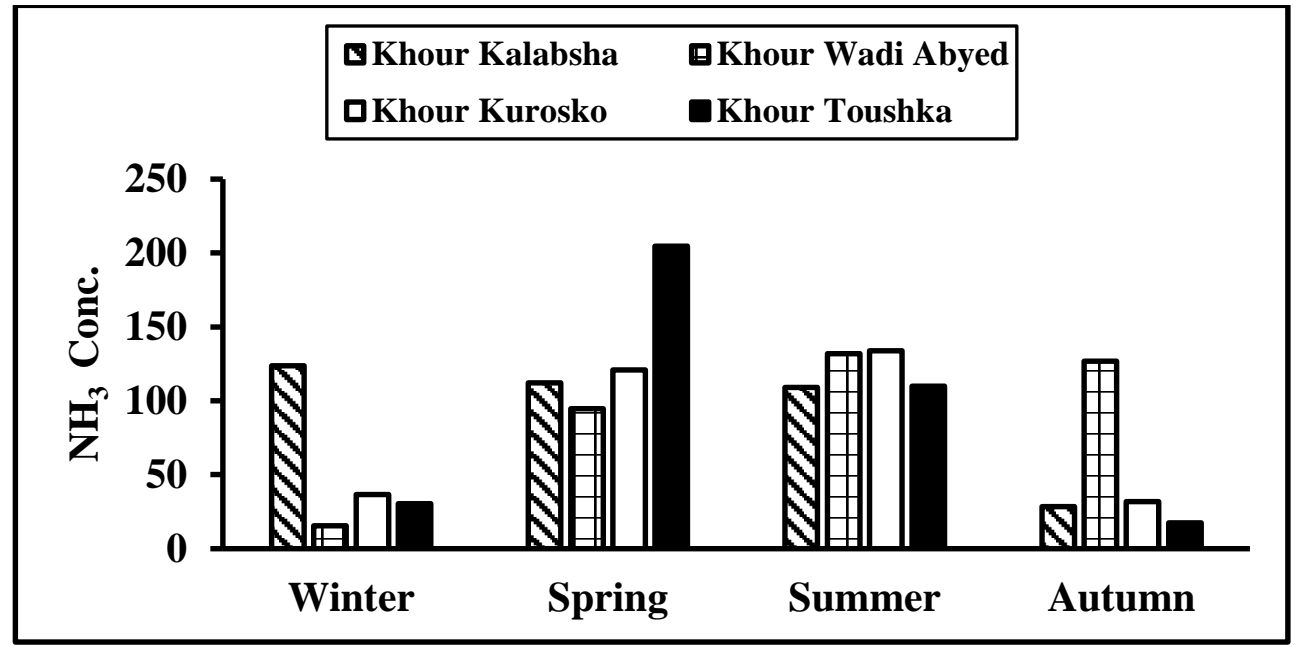

Fig. 5: Seasonal mean variations of $\mathrm{NH}_{3}-{\mathrm{N} \mu \mathrm{gl}^{-1}}^{-1}$ in different sites of each khor in Lake Nasser water during 2013.

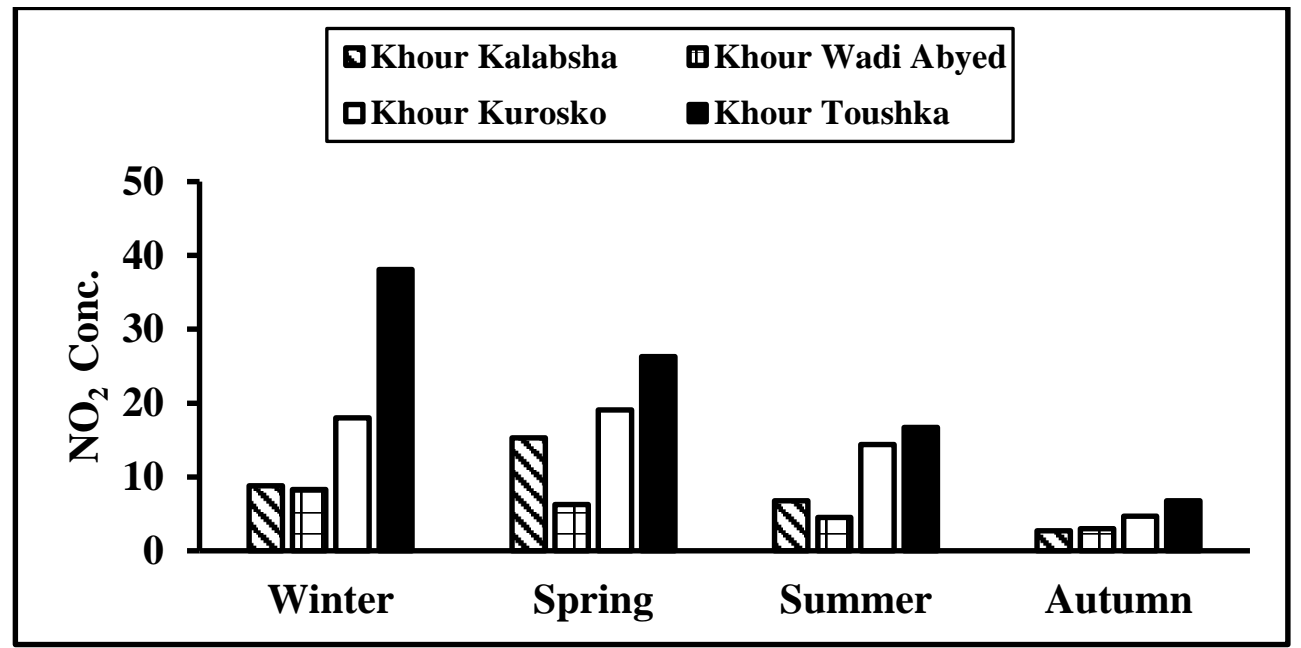

Fig. 6: Seasonal mean variations of $\mathrm{NH}_{2}-\mathrm{N} \mu \mathrm{gl}^{-1}$ in different sites of each khor in Lake Nasser water during 2013.

\subsection{Nitrate $\left(\mathrm{NO}_{3}^{-}-\mathrm{N}\right)$}

The seasonal of $\mathrm{NO}_{3}$ contents with a wide range of variations, these contents ranged from 87.51-3838.8, 77-920, 21-926 and 22.8-1124.8 ${\mu \mathrm{gl}^{-1}}^{1}$ in winter, spring, summer and autumn respectively. Higher nitrate concentrations were observed during winter (Tables 2-5, Fig. 7), this related to the complete oxidation of nitrogen compounds by nitrifying bacteria and biological 
nitrification as the fish excreta in water. In addition, during Nile flood water, organic matter inflowing to Lake Nasser water can be determine the nutrient status of man-made lakes (Kennedy and Walker, 1990). Drinking water containing a high concentration of nitrate is toxic, more than 50 ppm (according to standards of WHO, 1993) can cause many diseases. Latif and Elewa (1980) found that the concentration of $\mathrm{NO}_{3}^{-}$-Nitrogen ranged between 0.5-3.0 $\mathrm{mgl}^{-1}$. During 2006 the range was 2.4-44.1 $\mathrm{ggl}^{-1}$ (Goher and Ali, 2009). Recently, the high concentrations due to the agriculture farmland founded on the shore of lake a low amount of wastes in the lake water body at some khors. The lower values may be related to the reduction of $\mathrm{NO}_{3}^{-}$into $\mathrm{NO}_{2}^{-}$and $\mathrm{NH}_{3}$ by denitrifying bacteria or its consumption by phytoplankton.

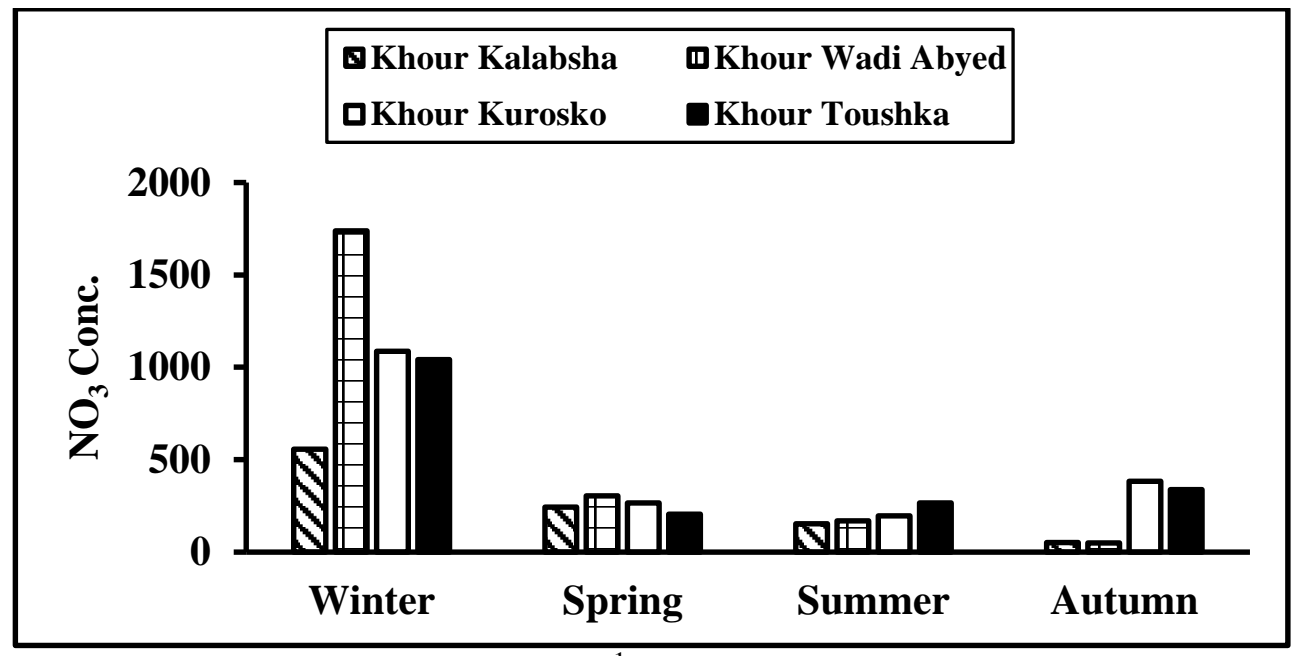

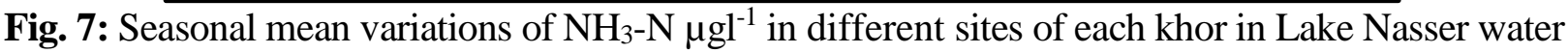
during 2013.

\subsection{Phosphate $\left(\mathrm{PO}_{4}^{3-}-\mathrm{P}\right)$}

Seasonal and regional variations of reactive soluble $\mathrm{PO}_{4}^{3-}$ concentration were ranged between 0.0 - 59.6 with complete depletion at K. Kalabsha, Wadi-Abyad and K. Korosko respectively during winter, while in other seasons fluctuated between 12-143, 6-312 and 15.1$92 \mu \mathrm{g} \mathrm{PO}{ }_{4}^{3-} 1^{-1}$ during spring, summer and autumn respectively. From the data obtained (Tables $2-$ 5, Fig. 8). The decrease in the phosphate values were probable due to adsorption of phosphorus on iron and aluminum hydroxide as a biotic process, in addition interchange with sediments and uptake by aquatic biota (Broberg and Persson ,1988). On the other side, the relative increase in $\mathrm{PO}_{4}^{3-}$ - $\mathrm{P}$ concentrations during winter are mainly regulated by dissolved oxygen (Sultan et al., 2005), also can be related to phosphorus release from the sediment and complete mixing of the water column. This can be demonstrated by the negative correlation $(\mathrm{r}=-0.483)$ between $\mathrm{PO}_{4}^{3-}$ $\mathrm{P}$ and D.O. concentrations (Table 6). Also the decrease in the $\mathrm{PO}_{4}^{3-}$ values during summer may be dropped occurred in phytoplankton biomass. From our data obtaind, the concentration of reactive phosphate were reduced compared with collected data in 1981 by Zaghloul (1985) that estimated reactive phosphate fluctuated between 70 and $520 \mu \mathrm{g} \mathrm{PO}_{4}^{3-} 1^{-1}$ and results collected in 1988 by Ali et al. (1995) that examine reactive phosphate which fluctuated between complete depletion and $1200 \mu \mathrm{g} \mathrm{PO}_{4}^{3-} \mathrm{l}^{-1}$ with average value $160 \mu \mathrm{g} \mathrm{PO}_{4}^{3-} \mathrm{l}^{-1}$, increase in phosphate level in fresh drinking water causes a diverse effect on heart and blood vessels. 


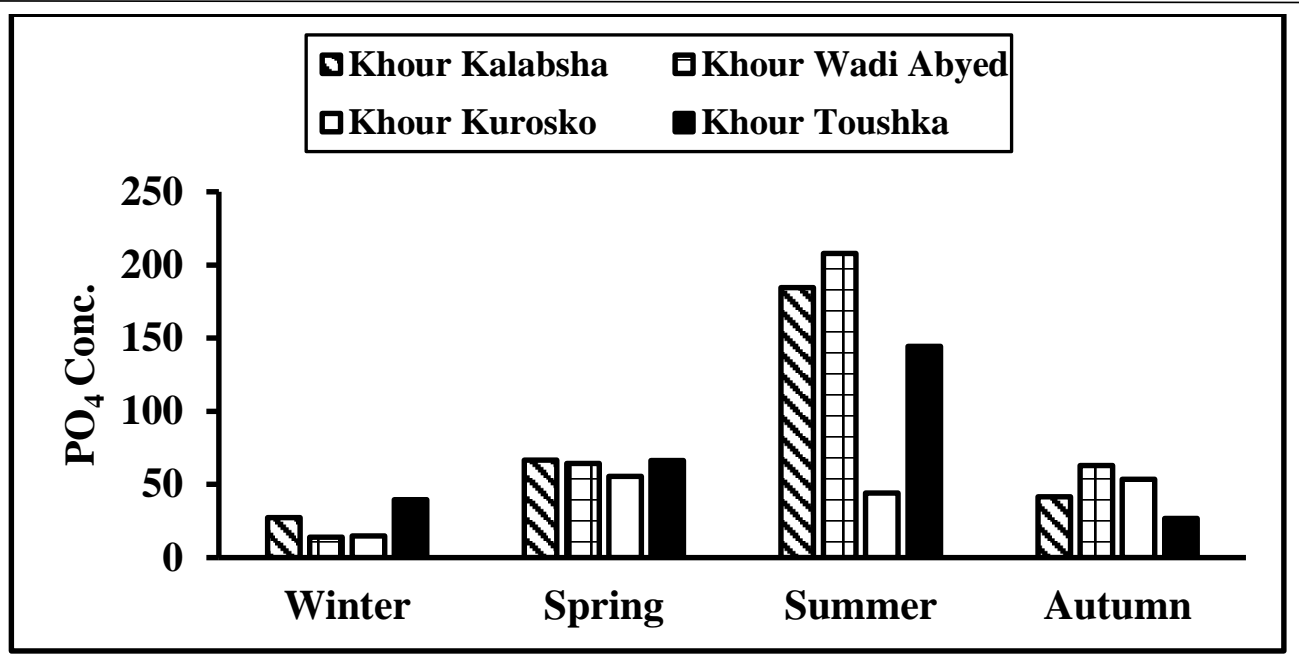

Fig. 8: Seasonal mean variations of $\mathrm{PO}_{4}^{3-}-\mathrm{P} \mu \mathrm{gl}^{-1}$ in different sites of each khor in lake Nasser water during 2013.

\subsection{Silica $\left(\mathrm{SiO}_{2}^{2-}\right)$}

The seasonal concentrations of reactive silicate fluctuated between 2.02-6.64, 1.7-8.21 and 1.7-8.9 $\mathrm{mgl}^{-1}$ respectively, during winter, summer and autumn, but the results not available during spring. The highest absolute and mean values were recorded during flood seasons (late summer and autumn) (Tables 3-4, Fig. 9), may be attributed to diatoms decomposition at high temperatures (Shabana, 1999). Generally the main factors affect on the distribution of silicate are temperature, dissolved oxygen, flood seasons rather than consumption by diatoms (Korium, 2001). Also fragmentation and consumption of the diatoms frustules may increase the dissolution silicate process by zooplankton (Ferrent and Barker, 1978). (Wetzel, 1983) reported that the alkaline $\mathrm{pH}$ of the water increase the dissolution of silicate from sediments to the upper water. Uptake silicate by the diatoms blooms, fungi, algae phytoplankton, zooplankton and fish cause the pronounce decrease in the silicate during winter or due to the limited solubility of silicate in water. These results obtained in this work applied with results by Anon (2005) recorded, the main value of $\mathrm{SiO}_{4}$ was 7-9 $\mathrm{mgl}^{-1}$ while (Goher and Ali, 2009 ; Abd El-Mola, 2009) mentioned that silicate concentrations varied from 0.51 to $3.7 \mathrm{mgl}^{-1}$ in Lake Nasser's water and with (Gharib et al., 2006), pointed to that concentrations of soluble silicate high above $0.6 \mu \mathrm{g} \mathrm{SiO}_{2}^{2-} 1^{-1}$.

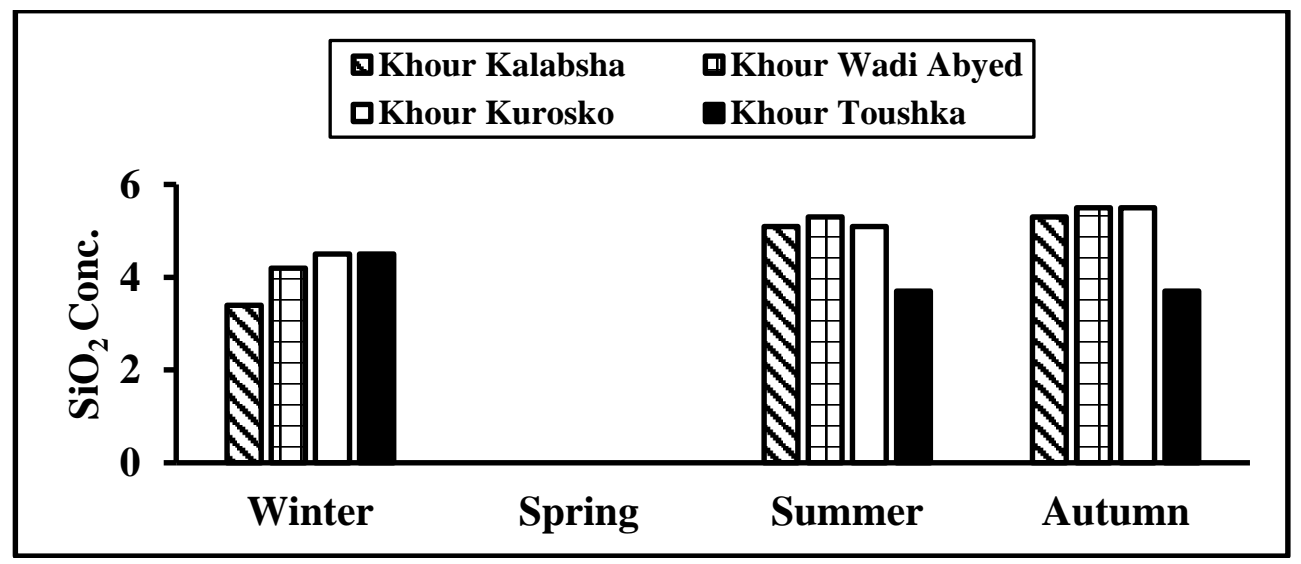

Fig. 9: Seasonal mean variations of $\mathrm{SiO}_{2}^{2-} \mathrm{mgl}^{-1}$ in different sites of each khor in lake Nasser water during 2013. 


\section{Conclusion}

From the results obtained during the present investigation, we have known that, all the physical-chemical and biological characteristics of khors in lake Nasser water were lie within permissible limits (desirable limits), and can be useful to pisiculture, irrigation and drinking water. Khors in lake Nasser can be affected by continuous human activity with a period of time, including agriculture and recreation lands around khors of the lake, tourism to Abu-Simple temple and commercial transportation between Egypt and Sudan.

Table ( 2 ): Regional mean variation of some parameters (physico-chemical) characteristics of water in main khors in Lake Nasser during winter (2013).

\begin{tabular}{|c|c|c|c|c|c|c|c|c|c|}
\hline \multirow{2}{*}{\multicolumn{2}{|c|}{ Stations }} & \multicolumn{8}{|c|}{ Parameters } \\
\hline & & \multirow{2}{*}{$\begin{array}{c}\text { Temp. } \\
{ }^{\circ} \mathbf{C} \\
17.0\end{array}$} & \multirow{2}{*}{$\begin{array}{l}\mathbf{p H} \\
8.62\end{array}$} & \multirow{2}{*}{$\frac{\begin{array}{c}\text { D.O } \\
\left(\mathbf{m g l}^{-1}\right)\end{array}}{4.70}$} & \multirow{2}{*}{$\begin{array}{c}\begin{array}{c}\mathrm{NH}_{3} \\
\left(\mathrm{Mgl}^{-1}\right)\end{array} \\
11.30\end{array}$} & \multirow{2}{*}{$\begin{array}{c}\begin{array}{c}\mathrm{NO}_{2} \\
\left(\boldsymbol{\mu g l}^{-1}\right)\end{array} \\
5.70\end{array}$} & \multirow{2}{*}{$\begin{array}{c}\begin{array}{c}\mathbf{N O}_{3} \\
\left(\mathbf{M g l}^{-1}\right)\end{array} \\
113.0\end{array}$} & \multirow{2}{*}{$\begin{array}{l}\mathbf{P O}_{4}^{3-} \\
\left(\boldsymbol{\mu g l ^ { - 1 } )}\right. \\
0.0\end{array}$} & \multirow{2}{*}{ 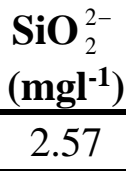 } \\
\hline \multirow{3}{*}{$\begin{array}{l}\text { Khor } \\
\text { Kalabsha }\end{array}$} & Min. & & & & & & & & \\
\hline & Max. & 19.7 & 9.33 & 8.10 & 318.5 & 13.3 & 1910.1 & 59.6 & 4.55 \\
\hline & Mean & 18.4 & 8.90 & 12.1 & 123.6 & 8.80 & 556.0 & 27.2 & 3.40 \\
\hline \multirow{3}{*}{$\begin{array}{l}\text { Khor Wadi } \\
\text { Abyed }\end{array}$} & Min. & 18.4 & 8.15 & 4.80 & 0.0 & 0.0 & 206.47 & 0.0 & 3.04 \\
\hline & Max. & 22.2 & 8.86 & 8.10 & 29.80 & 15.86 & 2513.7 & 28.0 & 5.61 \\
\hline & Mean & 19.9 & 9.0 & 5.90 & 15.50 & 8.30 & 1738.1 & 13.9 & 4.20 \\
\hline \multirow{3}{*}{$\begin{array}{l}\text { Khor } \\
\text { Kurosko }\end{array}$} & Min. & 18.1 & 8.0 & 4.20 & 4.650 & 7.79 & 87.51 & 0.0 & 2.02 \\
\hline & Max. & 22.3 & 9.37 & 8.10 & 52.40 & 31.92 & 3838.8 & 47.04 & 7.85 \\
\hline & Mean & 20.3 & 8.60 & 5.80 & 36.70 & 18.0 & 1087.0 & 14.90 & 4.50 \\
\hline \multirow{3}{*}{$\begin{array}{l}\text { Khor } \\
\text { Toushka }\end{array}$} & Min. & 17.5 & 8.32 & 5.40 & 1.860 & 7.85 & 173.3 & 25.58 & 2.10 \\
\hline & Max. & 20.6 & 8.90 & 8.20 & 105.4 & 76.35 & 2789.5 & 49.58 & 6.64 \\
\hline & Mean & 18.7 & 8.60 & 6.50 & 30.30 & 38.10 & 1041.8 & 39.50 & 4.50 \\
\hline
\end{tabular}

Table ( 3 ): Regional mean variation of some parameters (physico-chemical) characteristics of water in main khors in Lake Nasser during spring (2013).

\begin{tabular}{|c|c|c|c|c|c|c|c|c|c|}
\hline \multirow{2}{*}{\multicolumn{2}{|c|}{ Stations }} & \multicolumn{8}{|c|}{ Parameters } \\
\hline & & \multirow{2}{*}{$\begin{array}{c}\begin{array}{c}\text { Temp. } \\
{ }^{\circ} \mathbf{C}\end{array} \\
21.6 \\
\end{array}$} & \multirow{2}{*}{$\begin{array}{c}\mathbf{p H} \\
7.89 \\
\end{array}$} & \multirow{2}{*}{$\begin{array}{c}\begin{array}{c}\text { D.O } \\
\left(\mathrm{mgl}^{-1}\right)\end{array} \\
2.0\end{array}$} & \multirow{2}{*}{$\begin{array}{c}\begin{array}{c}\mathrm{NH}_{3} \\
\left(\boldsymbol{\mu g l}^{-1}\right)\end{array} \\
55 \\
\end{array}$} & \multirow{2}{*}{$\begin{array}{c}\begin{array}{c}\mathrm{NO}_{2} \\
\left(\mu \mathrm{gl}^{-1}\right)\end{array} \\
5.0\end{array}$} & \multirow{2}{*}{$\begin{array}{c}\begin{array}{c}\mathrm{NO}_{3} \\
\left(\boldsymbol{\mu g l}^{-1}\right)\end{array} \\
90 \\
\end{array}$} & \multirow{2}{*}{$\begin{array}{l}\mathbf{P O}_{4}^{3-} \\
\left(\mathbf{\mu g l}^{-1}\right) \\
38\end{array}$} & \multirow{2}{*}{$\begin{array}{c}\mathbf{S i O}_{2}^{2-} \\
\left(\mathrm{mgl}^{-1}\right)\end{array}$} \\
\hline & Min. & & & & & & & & \\
\hline Khor & Max. & 29.5 & 8.59 & 8.5 & 164 & 57 & 920 & 132 & 0.0 \\
\hline & Mean & 26.1 & 8.30 & 4.7 & 112.2 & 15.3 & 243.5 & 66.5 & 0.0 \\
\hline \multirow{3}{*}{$\begin{array}{l}\text { Khor Wadi } \\
\text { Abyed }\end{array}$} & Min. & 22.6 & 8.0 & 2.3 & 52 & 0.0 & 90 & 12 & 0.0 \\
\hline & Max. & 29.6 & 9.0 & 6.2 & 215 & 14 & 560 & 143 & 0.0 \\
\hline & Mean & 26.2 & 9.0 & 4.9 & 94.6 & 6.3 & 303.8 & 64.4 & 0.0 \\
\hline \multirow{3}{*}{$\begin{array}{l}\text { Khor } \\
\text { Kurosko }\end{array}$} & Min. & 21.9 & 7.72 & 1.9 & 18 & 0.0 & 77 & 14 & 0.0 \\
\hline & Max. & 31.4 & 8.72 & 6.3 & 501 & 108 & 642 & 95 & 0.0 \\
\hline & Mean & 27.9 & 8.40 & 4.3 & 121 & 19.1 & 266.8 & 55.6 & 0.0 \\
\hline \multirow{3}{*}{$\begin{array}{l}\text { Khor } \\
\text { Toushka }\end{array}$} & Min. & 25.3 & 7.64 & 1.7 & 93 & 7.0 & 93 & 54 & 0.0 \\
\hline & Max. & 31.8 & 8.61 & 6.0 & 400 & 58 & 400 & 87 & 0.0 \\
\hline & Mean & 29.1 & 8.30 & 4.4 & 204.6 & 26.3 & 204.5 & 66.3 & 0.0 \\
\hline
\end{tabular}


Table ( 4 ): Regional mean variation of some parameters (physico-chemical) characteristics of water in main khors in Lake Nasser during summer (2013).

\begin{tabular}{|c|c|c|c|c|c|c|c|c|c|}
\hline \multirow{2}{*}{ Stations } & & \multicolumn{8}{|c|}{ Parameters } \\
\hline & & $\begin{array}{c}\text { Temp. } \\
{ }^{\circ} \mathrm{C}\end{array}$ & pH & $\begin{array}{c}\text { D.O } \\
\left(\mathrm{mgl}^{-1}\right)\end{array}$ & $\begin{array}{c}\mathrm{NH}_{3} \\
\left(\mu \mathrm{gl}^{-1}\right)\end{array}$ & $\begin{array}{c}\mathrm{NO}_{2} \\
\left(\mu \mathrm{gl}^{-1}\right)\end{array}$ & $\begin{array}{c}\mathrm{NO}_{3} \\
\left(\mu \mathrm{gl}^{-1}\right)\end{array}$ & $\begin{array}{l}\mathbf{P O}_{4}^{3-} \\
\left(\mu g^{-1}\right)\end{array}$ & $\begin{array}{l}\mathrm{SiO}_{2}^{2-} \\
\left(\mathrm{mgl}^{-1}\right)\end{array}$ \\
\hline \multirow{3}{*}{$\begin{array}{l}\text { Khor } \\
\text { Kalabsha }\end{array}$} & Min. & 25.4 & 7.21 & 1.9 & 49 & 5.0 & 63 & 120 & 3.28 \\
\hline & Max. & 30.4 & 8.33 & 5.0 & 267 & 9.0 & 492 & 312 & 7.22 \\
\hline & Mean & 28.5 & 8.0 & 4.2 & 109 & 6.8 & 152.1 & 184.6 & 5.10 \\
\hline \multirow{3}{*}{$\begin{array}{l}\text { Khor Wadi } \\
\text { Abyed }\end{array}$} & Min. & 24.3 & 8.0 & 0.9 & 44 & 4.0 & 58 & 130 & 2.59 \\
\hline & Max. & 30.8 & 8.0 & 5.5 & 685 & 6.0 & 331 & 315 & 8.21 \\
\hline & Mean & 28.7 & 8.0 & 3.7 & 132 & 4.5 & 167.6 & 207.8 & 5.30 \\
\hline \multirow{3}{*}{$\begin{array}{l}\text { Khor } \\
\text { Kurosko }\end{array}$} & Min. & 26.2 & 7.78 & 1.6 & 18 & 8.0 & 21 & 6.0 & 3.33 \\
\hline & Max. & 31.7 & 8.86 & 5.7 & 495 & 34 & 926 & 194 & 6.93 \\
\hline & Mean & 30.0 & 8.30 & 3.5 & 133.8 & 14.4 & 195.6 & 44.1 & 5.10 \\
\hline \multirow{3}{*}{$\begin{array}{l}\text { Khor } \\
\text { Toushka }\end{array}$} & Min. & 28.2 & 8.21 & 3.0 & 55 & 10 & 101 & 100 & 1.70 \\
\hline & Max. & 31.3 & 8.65 & 5.0 & 198 & 29 & 543 & 190 & 6.0 \\
\hline & Mean & 29.6 & 8.40 & 4.3 & 110 & 16.7 & 266.2 & 144.3 & 3.70 \\
\hline
\end{tabular}

Table ( 5 ): Regional mean variation of some parameters (physico-chemical) characteristics of water in main khors in Lake Nasser during autumn (2014).

\begin{tabular}{|c|c|c|c|c|c|c|c|c|c|}
\hline \multirow{2}{*}{ Stations } & & \multicolumn{8}{|c|}{ Parameters } \\
\hline & & $\begin{array}{c}\text { Temp. } \\
{ }^{\circ} \mathrm{C}\end{array}$ & pH & $\begin{array}{c}\text { D.O } \\
\left(\mathrm{mgl}^{-1}\right)\end{array}$ & $\begin{array}{c}\mathrm{NH}_{3} \\
\left(\mu \mathrm{gl}^{-1}\right)\end{array}$ & $\begin{array}{c}\mathrm{NO}_{2} \\
\left(\mu \mathrm{gl}^{-1}\right)\end{array}$ & $\begin{array}{c}\mathrm{NO}_{3} \\
\left(\mu \mathrm{gl}^{-1}\right)\end{array}$ & $\begin{array}{l}\mathbf{P O}_{4}^{3-} \\
\left(\mu^{-1}\right)\end{array}$ & $\begin{array}{l}\mathrm{SiO}_{2}^{2-} \\
\left(\mathrm{mgl}^{-1}\right)\end{array}$ \\
\hline \multirow{3}{*}{$\begin{array}{l}\text { Khor } \\
\text { Kalabsha }\end{array}$} & Min. & 22.8 & 7.98 & 6.0 & 18.48 & 1.6 & 25.84 & 21.42 & 2.1 \\
\hline & Max. & 27.2 & 8.53 & 7.8 & 56.28 & 4.8 & 144.4 & 63.0 & 6.6 \\
\hline & Mean & 24.9 & 8.30 & 6.5 & 28.40 & 2.7 & 51.30 & 41.5 & 5.3 \\
\hline \multirow{3}{*}{$\begin{array}{l}\text { Khor } \\
\text { Wadi } \\
\text { Abyed }\end{array}$} & Min. & 21.3 & 8.0 & 1.4 & 19.3 & 2.0 & 22.80 & 42.8 & 3.6 \\
\hline & Max. & 24.9 & 8.0 & 7.3 & 810 & 4.4 & 98.80 & 92.0 & 8.3 \\
\hline & Mean & 23.6 & 8.0 & 5.4 & 126.7 & 3.0 & 49.40 & 62.9 & 5.5 \\
\hline \multirow{3}{*}{$\begin{array}{l}\text { Khor } \\
\text { Kurosko }\end{array}$} & Min. & 23.4 & 7.31 & 2.5 & 10.0 & 2.0 & 106.4 & 22.7 & 2.1 \\
\hline & Max. & 26.4 & 8.37 & 7.2 & 172.2 & 19.6 & 1124.8 & 87.0 & 8.9 \\
\hline & Mean & 24.9 & 7.90 & 5.1 & 31.8 & 4.7 & 382.4 & 53.5 & 5.5 \\
\hline \multirow{3}{*}{$\begin{array}{l}\text { Khor } \\
\text { Toushka }\end{array}$} & Min. & 22.7 & 8.49 & 6.8 & 11.0 & 2.8 & 136.8 & 15.1 & 1.7 \\
\hline & Max. & 24.9 & 8.77 & 8.4 & 37.0 & 18.4 & 456 & 44.0 & 6.0 \\
\hline & Mean & 23.4 & 8.60 & 7.7 & 17.5 & 6.80 & 337.5 & 26.8 & 3.7 \\
\hline
\end{tabular}

Table (6): Correlation coefficient (r) among mean physic-chemical parameters of different sites in the main lake Nasser khors.

\begin{tabular}{cccccccc}
\hline & Temp. & pH & D.O & $\mathbf{N H}_{3}$ & $\mathbf{N O}_{2}$ & $\mathbf{N O}_{3}$ & $\mathbf{P O}_{4}$ \\
\hline pH & -0.547 & & & & & & \\
D.O & -0.753 & 0.514 & & & & & \\
NH3 & 0.603 & -0.288 & -0.278 & & & & \\
\hline
\end{tabular}




\begin{tabular}{lccccccc}
\hline & Temp. & $\mathbf{p H}$ & $\mathbf{D . O}$ & $\mathbf{N H}_{3}$ & $\mathbf{N O}_{2}$ & $\mathbf{N O}_{3}$ & $\mathbf{P O}_{4}$ \\
\hline $\mathbf{N O}_{2}$ & -0.116 & 0.183 & -0.086 & 0.129 & & & \\
$\mathbf{N O}_{3}$ & -0.706 & 0.617 & 0.264 & -0.552 & 0.302 & & \\
$\mathbf{P O}_{4}$ & 0.625 & -0.548 & -0.483 & 0.424 & -0.188 & -0.461 & \\
$\mathbf{S i O}_{2}$ & -0.222 & -0.355 & 0.094 & -0.421 & -0.330 & 0.116 & 0.144 \\
\hline
\end{tabular}

\section{References}

Abd El-Mola, H.R. (2009): Ecological studies on planktonic and epiphytic micro invertebrates in Lake Nasser Ph.D. Thesis, Fac. Of Sci., Benha Univ. Egypt. 207pp.

Abd El-Monem, A.M. (1995): Spatial distribution of phytoplankton and primary productivity in Lake Nasser. Ph.D. Thesis, Fac. Sci., College Girls. Ain Shams Univ., 161pp.

Ali, M.M., Hamad, A.M., Springuel, I.V. and Murphy, K.J. (1995): Environmental factors affecting submerged macrophyte communities in regulated water bodies in Egypt. Arch. Hydrobiol. 133(1): 107-128.

Anon, 2005: Nile Basin Initiative and Nile Trans-boundary Environmental Action Project, 2005. Nile Basin National Water Quality Monitoring Baseline Study Report for Egypt.

APHA (1998): Standard methods for the examination of water and wastewater. $20^{\text {th }}$ ed. American Public Health Association, Washington, DC.

Benson, B.B. and Krause, D.J., The concentration and isotopic fractionation of gases dissolved in fresh water in equilibrium with the atmosphere. Oxygen, Limnol. Oceanogr, 25; 662-671 (1980).

Broberg, O. and Persson, G.: Particulate and dissolved phosphorus forms in freshwater; composition and analysis. Hydrobiolo., 170: 61 - 90 (1988).

Chen C.Y and Durbin, E.G. (1994): Effects of pH on the growth and carbon uptake of marine phytoplankton. Mar Ecol Prog Ser 109: 83-94.

Elewa, A.A. (1988): Preliminary analysis of khors water in Lake Nasser. Bull. Inst. Oceanogr. Fisher. 11: 43 - 52.

El-Halag, R.S.F.; Shaker, I.M.; Mehanna, S.F.; Othman, M.F. and Farouk, A., Impact of some environmental condition on water quality and some heavy metals in water from Bardawil Lake. New York Science Journal 2013; 6(11).

El-Shabrawy, G.M. (2014): Ecological Basis for Lake Nasser Ecosystem. Lap Lambert Academic Publishing, Norderstedt, Germany, Pages: 269.

El-Shabrawy, G.M. and Dumont, H.J. (2003): Spatial and seasonal variation of the zooplankton in the coastal zone and main khors of Lake Nasser (Egypt). Hydrobiologia 491:119-132.

Entz, B.A.G., 1973. Morphometry of lake Nasser. Lake Nasser Development Center, Working Paper No. 2, Aswan, Egypt, pp: 81.

Ferrent, J.G. and Barker, J., The influence of planktonic and benthic crustaceans on silicon cycling in Lake Michigan, U.S.A., Verh. Int. Limnol., 20: 324(1978).

Gharib SM, Abdel-Halim A.M. (2006): Spatial variation of phytoplankton and some physicochemical variables during the highest flood season in Lake Nasser (Egypt). Egypt Journal of Aquat Research 1687-4285 vol. 32 no. 1: 246-263. 
Goher, M.E. and M.H. Ali, M.H. (2009): Monitoring of water quality characteristics and some heavy metals, in water, sediment and macrophytes in main khors of Lake Nasser, Egypt. J. Egypt. Acad. Soc. Environ. Develop., 10(4): 109-122.

Goldman, C.R. and Horne, A.J., Limnology International Student Edition, McGraw-Hill International Book Company, London, 197-220 (1983).

Goma,R.H (2001): Seasonal and spatial variation of nutrient in the main channel of Lake Nasser. Working Report of Fishery Management Center vol. 6, pp 75-122.

Hesham R. Abdel Mola, Soad S. Abdel Gawad: Spatiotemporal of macrobenthic fauna in Lake Nasser khors, Egypt. The Egyptian Journal of Aquatic Research, vol 40, Issue 4, 2014, pages $415-423$.

Howayda, H. Abd El-Hady; Shadia A. Fathey; Gamila H. Ali and Yasmin G. Gabr: Biochemical profile of phytoplankton and its nutritional aspects in some khors of Lake Nasser, Egyptian Journal of Basic and Applied Science vol. 3, Issue 2, June 2016, pages 187-193.

Hutchinson, G.E., Atreatise on limnology. 111. Limnological Botany. Willey, New York, U.S.A (1975).

Iskaros, I.A. (1993): Ecological studies on the distribution of zooplankton and bottom fauna in Khor Kalabsha in lake Nasser. Ph.D. Thesis, Fac. Sci, Mansoura Uni., 304 pp.

K.W. Thomton, B.L. Kimmel, F.E. Payne (Eds), Reservoir limnology; Ecological Perpectives. Wiley, New York (1990), pp. 109-131.

Kennedy Walker 1990 R.H Kennedy. W.W. Walker Reservoir nutrient dynamics.

Korium, M.A. (2001): Some studies on the distribution of trace and major elements in High Dam Lake, Ph.D. Thesis, Fac. Of Sci. El-Azhar Univ. 213pp.

Latif, A.F.A. (1984): Lake Nasser. The new man-made lake in Egypt (with reference to Lake Nubia). In: Taub FB, editor. Ecosystems of the world 32, lakes and reservoir: p. 385-416.

Latif, A.F.A. and Elewa, A.A. (1980): Physico-chemical Characteristics of Lake Nasser and Lake Nubian. Report on surveys to Lake Nasser and River Nile Project. Academy of Scientific Research and Technology, Cairo, Egypt, 105pp.

Rabeh, S.A. (2001): Sanitary quality of water of some important khors of lake Nasser, Egypt. J. Egypt. Acad. Soc. Environ. Dev., 2: 1-18.

Shabana, E.E. (1999): Limnological studies on lake Bardawil, M. Sc. Thesis, Fac. Sci., Suez Canal Univ., Egypt.

Shiddamallayya, N. and Pratima, M. (2008): Impact of domestic sewage on freshwater body. Indian J. Environ. Cons. 8: 289-292.

Singh, J.; Agrawal D.K. and Panwar, S. (2008): Seasonal variation in different physicochemical variation in different physicochemical characteristics of Yamuna River water quality in proposed lakhwar hydropower project influence area. International Journal of Applied Environmental Sciences 3(1): $107-117$.

Sultan, M.E.; Moalla, S. M.N.; Rashed, M.N. and Fawzy, E.M. (2005): Physicochemical characteristics and distribution of some metals in the ecosystem of lake Nasser, Egypt. Toxicol Environ. Chem, 87, pp. 167-197.

Toma, J.J. (2011): Physical and Chemical properties and Algal composition of Derbendi Khan Lake, Sulaimania, Iraq, Current World Environment. Vol. 6(1), 17-27. 
Toufeek M.E.F. and Korium, M.A. (2015): Impact of physic-chemical characteristics of some khors of Lake Nasser, Egypt. Curr. Sci. Inter. Vol:04/ Issue: 03/July-Sept./ 2015.

Trivedy, R.K. (1989): Limnology of freshwater pond in Mangalore. National Symposium on Advances in Limnology Conservation of Endangered Fish Species. Oct. 23-25 Sprinagar Garhwal.

Wetzel, R.G. (1983): Limnology, Saunders College Publishing $2^{\text {nd }}$ ed. 767, pp: 733.

WHO (World health organization). Guidelines for drinking water quality $2^{\text {nd }}$ edition, vol. 1 , Recommendations, 1993.

Zaghloul, F.A. (1985): Seasonal variation of plankton in lake Nasser. Ph.D. Thesis, Fac. Science, Suez Canal Univ. Egypt. 364 pp. 